\title{
Microwave Assisted One Pot Synthesis of Tetrazole Based 3-hydroxy-4H- chromen-4-ones by Modified Algar-Flynn-Oyamada Reaction and their Antimicrobial Activity
}

\author{
Dongamanti Ashok ${ }^{1, *}$, Nalaparaju Nagaraju ${ }^{1}$, Madderla Sarasija ${ }^{2}$, Bommidi Vijaya Lakshmi ${ }^{1}$ \\ ${ }^{1}$ Green and Medicinal Chemistry laboratory, Department of Chemistry, Osmania University, Hyderabad-500 \\ 007, Telangana, India. \\ ${ }^{2}$ Department of Chemistry, Satavahana University, Karimnagar, 505001, Telangana, India.
}

*Corresponding author: Dongamanti Ashok e-mail: ashokdou@gmail.com

Received December $1^{\text {st }}, 2018$; Accepted July 15 $5^{\text {th }}, 2019$.

DOI: http://dx.doi.org/10.29356/jmcs.v63i4.448

\begin{abstract}
In the present work, we report the one pot synthesis of tetrazole based 3-hydroxy-4H-chromen-4ones 3(a-g) from 4-(1H-tetrazol-5-yl)benzaldehyde and 2-hydroxy acetophenone using $\mathrm{KOH}$ and $\mathrm{H}_{2} \mathrm{O}_{2}$ by modified Algar-Flynn-Oyamada reaction under conventional and microwave irradiation conditions. In this technique, flavonols are synthesized without isolating chalcones, in good yields. All the synthesized compounds were characterized by IR, NMR, MS and elemental analysis. All newly synthesized compounds were screened for their in-vitro antimicrobial activity against strains such as Staphylococcus aurous, Bacillus subtilis, Klebsiella pneumonia, Escherichia coli, Aspergillus Niger, Aspergillus flavus, and Fusarium oxysporum. The results of antimicrobial studies revealed that most of the compounds exhibit good activity.
\end{abstract}

Keywords: 2-hydroxy acetophenone; 4-(1H-tetrazol-5-yl) benzaldehyde; microwave irradiation; antimicrobial activity.

Resumen. En este trabajo se reporta la síntesis en un matraz (one-pot) de tetrazol basada en 3-hidroxi-4Hcromen-4-onas 3(a-g) a partir de 4-(1H-tetrazol-5-yl) benzaldehído y 2-hidroxi acetofenona utilizando KOH y $\mathrm{H}_{2} \mathrm{O}_{2}$ de acuerdo con la reacción de Algar-Flynn-Oyamada modificada bajo condiciones de reacción convencionales y de microondas. En esta técnica, se sintetizan flavonoles con buen rendimiento, sin aislar calconas. Todos los compuestos sintetizados se caracterizaron por IR, NMR, MS y análisis elemental. su La actividad antimicrobiana de todos los compuestos sintetizados por primera vez se probó in vitro contra cepas como Staphylococcus aurous, Bacillus subtilis, Klebsiella pneumonia, Escherichia coli, Aspergillus Niger, Aspergillus flavus y Fusarium oxysporum. Los resultados de los estudios antimicrobianos revelaron que la mayoría de los compuestos tienen una buena actividad.

Palabras clave: 2-hidroxiacetofenona; 4-(1H-tetrazol-5-yl) benzaldehído; irradiación microondas; actividad antimicrobiana.

\section{Introduction}

Heterocyclic compounds containing nitrogen and oxygen play an imperative role during the design of agrochemicals and pharmaceuticals. Flavonols (3-Hydroxyflavone) belongs to a class of flavonoids and their 
derivatives are known to possess various biological activities such as anticancer [1], antihypertensive [2], cytotoxic [3], antimicrobial [4], antioxidant [5], anti-inflammatory [6], free radical scavenging [7]. The synthesis of 3-hydroxy flavones was first described by Algar, Flynn and Oyamada [8,9] and was later modified by Murakami and Irie, Reichel and Steudel $[10,11]$. The original AFO reaction is a two-step process in which the first step involves the formation of 2-hydroxy chalcone intermediate which on subsequent cyclization in the second step in the presence of alkaline hydrogen peroxide affords the corresponding flavonols whereas the modified AFO reaction is a one-step process in which the flavonols derivatives were obtained without isolation of the intermediate 2-hydroxy chalcone in the presence of alkaline hydrogen peroxide.

Tetrazole is a key structural motif in heterocyclic chemistry that contains four nitrogens and one carbon atom in a five membered ring skeleton and has been successfully explored in the design of drug molecules [12]. Tetrazole can act as pharmacophore for carboxylate group. Tetrazole and their derivatives are known to possess broad range of biological activities such as antioxidant, antibacterial [13-15], anticancer [16], antihypertensive [17], antitubercular [18], antifungal [19] and anticonvulsant [20].

Throughout recent years, microwave method $[21,22]$ is extensively used as a non-conventional source of energy to carry out various organic reactions because of the advantages of shorter reaction times, high yields, selectivity, consumption of a small amount of energy, low quantities of side products, and easier work up technique over conventional method.

Inspired by the biological activity of tetrazole, flavonol derivatives and also in continuation to our research work done earlier on the synthesis of flavonol derivatives, we devised the synthesis of novel hybrid molecules containing these active pharmacophore under conventional and microwave irradiation methods. All the synthesized compounds were screened in vitro for their antimicrobial activity.

\section{Experimental}

All the available reagent grade chemicals were purchased from Sigma Aldrich, and were used without further purification. Microwave reactions were carried out in Milestone multi SYNTH microwave system. The reactions were monitored by TLC on Merck Kieselgel $60 \mathrm{~F} 524$, by UV light and/or spraying a $5 \% \mathrm{H}_{2} \mathrm{SO}_{4}$ in Ethanol followed by heating. Column chromatography was performed on Silica Gel 60 (60-120 mesh). Melting points were determined in open glass capillaries on a Stuart SMP30 apparatus and are uncorrected. Element analysis was carried out with Thermofinnigan CHNS analyzer. IR spectrum was recorded in $\mathrm{KBr}$ on a Shimadzu FTIR 8400S spectrophotometer. NMR spectra were recorded on a Bruker 400 NMR spectrometer in $\mathrm{CDCl} 3$ using TMS as internal standardand mass spectra were recorded by the Shimadzu mass spectrometer.

\section{General procedure for the Synthesis of substituted 2-(4-(1H-tetrazol-5-yl)phenyl)-3-hydroxy- 4H-chromen-4-ones 3(a-g) Conventional heating method}

To a well stirred solution of 4-(1H-tetrazol-5-yl) benzaldehyde (1) (1 mmol) and 2hydroxyacetophenones $2(\mathbf{a}-\mathbf{g})(1 \mathrm{mmol})$ in ethanol $(20 \mathrm{ml})$, was added $\mathrm{KOH}(4 \mathrm{mmol}$ in $10 \mathrm{~mL}$ of EtOH$)$ at room temperature. The reaction mixture was further stirred for $8 \mathrm{~h}$. After completion of the reactants (as indicated by TLC), the reaction mixture was dissolved in aqueous $\mathrm{KOH}(5 \mathrm{mmol}$ in $5 \mathrm{~mL}), 3 \mathrm{~mL}$ of $30 \% \mathrm{H}_{2} \mathrm{O}_{2}$ was added drop wise and continued the stirring for $6 \mathrm{~h}$. After completion of reaction (as monitored by TLC), the resultant light yellow reaction mixture was poured on crushed ice and neutralized with dil. HCl. The light yellow solid obtained was filtered and dried. The crude product was purified by column chromatography using a mixture of EtOAc: hexane $(7: 3 \mathrm{v} / \mathrm{v})$ to afford pure desired $\mathbf{3}(\mathbf{a}-\mathbf{g})$ as the respective yields are shown in Table 1.

\section{Microwave irradiation method}

A mixture of 4-(1H-tetrazol-5-yl) benzaldehyde (1) $(1 \mathrm{mmol})$ and 2-hydroxyacetophenones 2(a-g) (1 mmol) in ethanol $(20 \mathrm{ml})$, was added $\mathrm{KOH}(4 \mathrm{mmol}$ in $10 \mathrm{~mL}$ of EtOH) was taken through a quartz tube and inserted into a teflon vial with screw capped and subjected to microwave irradiation at $180 \mathrm{~W}$ for 6 min, with 
an interval of $30 \mathrm{sec}$. After consumption of the majority of reactants (as indicated by TLC), aqueous KOH ( 5 mmol in $5 \mathrm{~mL}$ ), $3 \mathrm{~mL}$ of $30 \% \mathrm{H}_{2} \mathrm{O}_{2}$ was added drop wise to the reaction mixture and continued the irradiation for $3 \mathrm{~min}$. After completion of reaction (as monitored by TLC), the resulting light yellow reaction mixture was poured over crushed ice and neutralized with dil. $\mathrm{HCl}$. The light yellow solid thus obtained was filtered, washed with water and dried. The crude product was purified by column chromatography on silica gel using EtOAc: hexane $(7: 3 v / v)$ as eluant to give the pure desired $\mathbf{3}(\mathbf{a}-\mathbf{g})$ as the respective yields are shown in Table 1.

\section{2-(4-(1H-tetrazol-5-yl)phenyl)-3-hydroxy-4H-chromen-4-one (3a)}

A pale yellow solid: Yield 81\%, mp 192-194 ${ }^{\circ} \mathrm{C}$; IR (KBr) vmax $3411(\mathrm{OH}), 3361(\mathrm{NH}), 1608(\mathrm{C}=\mathrm{O})$; ${ }^{1} \mathrm{H}$ NMR (DMSO- $\left.d_{6}, 400 \mathrm{MHz}\right) \delta 7.01-7.05 \mathrm{~m}(2 \mathrm{H}, \mathrm{Ar}-\mathrm{H}), 7.22 \mathrm{~s}(1 \mathrm{H}, \mathrm{OH}), 7.59 \mathrm{t}(1 \mathrm{H}, J=7.02 \mathrm{~Hz}, \mathrm{Ar}-\mathrm{H})$, 7.94-7.95 m $(4 \mathrm{H}, \mathrm{Ar}-\mathrm{H}), 8.07 \mathrm{~d}(1 \mathrm{H}, J=2.56 \mathrm{~Hz}, \mathrm{Ar}-\mathrm{H}) ;{ }^{13} \mathrm{C}$ NMR (DMSO- $\left.d_{6}, 100 \mathrm{MHz}\right) \delta 121.9,123.5$, $129.0,132.5,132.8,134.4,134.7,139.3,140.4,141.0,149.2,158.2,164.4,178.2$; ESI MS $m / z$ (rel int): 307 $(\mathrm{M}+\mathrm{H})^{+}(100)$. Anal. Calcd for $\mathrm{C}_{16} \mathrm{H}_{10} \mathrm{~N}_{4} \mathrm{O}_{3}$ : C 62.76; H 3.31; N 18.31. Found: C 62.74; H 3.29; N 18.29.

\section{2-(4-(1H-tetrazol-5-yl)phenyl)-6-fluoro-3-hydroxy-4H-chromen-4-one (3b)}

A pale yellow solid: Yield 79\%, mp 171-173 ${ }^{\circ} \mathrm{C}$. IR ( $\left.\mathrm{KBr}\right)$ vmax $3522(\mathrm{OH}), 3363(\mathrm{NH}), 1606(\mathrm{C}=\mathrm{O})$. ${ }^{1} \mathrm{H}$ NMR (DMSO- $\left.d_{6}, 400 \mathrm{MHz}\right) \delta 6.85 \mathrm{~d}(1 \mathrm{H}, \mathrm{Ar}-\mathrm{H}), 7.03 \mathrm{~s}(1 \mathrm{H}, \mathrm{OH}), 7.38-7.41 \mathrm{dd}(1 \mathrm{H}, J=8.80 \mathrm{~Hz}, J=2.56$ $\mathrm{Hz}, \mathrm{Ar}-\mathrm{H}), 7.94-7.95 \mathrm{~m}(4 \mathrm{H}, \mathrm{Ar}-\mathrm{H}), 8.07 \mathrm{~d}(1 \mathrm{H}, J=2.56 \mathrm{~Hz}, \mathrm{Ar}-\mathrm{H}) .{ }^{13} \mathrm{C}$ NMR (DMSO- $\left.d_{6}, 100 \mathrm{MHz}\right) \delta 122.3$, 125.0, 127.9, 131.6, 133.5, 138.1, 139.2, 139.8, 143.7, 148.0, 157.0, 163.2, 170.7, 177.0; ESI MS $m / z$ (rel int): $325(\mathrm{M}+\mathrm{H})^{+}(100)$. Anal. Calcd for $\mathrm{C}_{16} \mathrm{H}_{9} \mathrm{FN}_{4} \mathrm{O}_{3}$ : C 59.28; H 2.82; N 17.30. Found: C 59.26; H 2.80; N 17.28 .

\section{2-(4-(1H-tetrazol-5-yl)phenyl)-6-chloro-3-hydroxy-4H-chromen-4-one (3c)}

A pale yellow solid: Yield 84\%, mp 184-186 ${ }^{\circ} \mathrm{C}$. IR (KBr) vmax $3523(\mathrm{OH}), 3361(\mathrm{NH}), 1606(\mathrm{C}=\mathrm{O})$. ${ }^{1} \mathrm{H}$ NMR (DMSO- $\left.d_{6}, 400 \mathrm{MHz}\right) \delta 7.05 \mathrm{~d}(1 \mathrm{H}, J=8.80 \mathrm{~Hz}, \mathrm{Ar}-\mathrm{H}), 7.23 \mathrm{~s}(1 \mathrm{H}, \mathrm{OH}), 7.58-7.61 \mathrm{dd}(1 \mathrm{H}, J=8.80$ $\mathrm{Hz}, J=2.57 \mathrm{~Hz}, \mathrm{Ar}-\mathrm{H}), 8.14-8.15 \mathrm{~m}(4 \mathrm{H}, \mathrm{Ar}-\mathrm{H}), 8.27 \mathrm{~d}(1 \mathrm{H}, J=2.57 \mathrm{~Hz}, \mathrm{Ar}-\mathrm{H}) .{ }^{13} \mathrm{C}$ NMR (DMSO- $d_{6}, 100$ MHz) $\delta 122.9,123.5,126.2,129.0,132.5,132.8,134.4,134.7,140.4,141.0,144.9,149.2,158.2$, 178.2; ESI MS $m / z$ (rel int): $341(\mathrm{M}+\mathrm{H})^{+}(100)$. Found: $\mathrm{C} 56.40 ; \mathrm{H} 2.66$; N 16.44.Anal. Calcd for $\mathrm{C}_{16} \mathrm{H}_{9} \mathrm{ClN}_{4} \mathrm{O}_{3}$ : C 56.42; H 2.68; N 16.46 .

\section{2-(4-(1H-tetrazol-5-yl)phenyl)-6-bromo-3-hydroxy-4H-chromen-4-one (3d)}

A pale yellow solid: Yield $82 \%, \mathrm{mp} 172-173^{\circ} \mathrm{C}$. IR (KBr) vmax $3523(\mathrm{OH}), 3424(\mathrm{NH}), 1620(\mathrm{C}=\mathrm{O})$. ${ }^{1} \mathrm{H}$ NMR (DMSO- $\left.d_{6}, 400 \mathrm{MHz}\right) \delta 6.82 \mathrm{~d}(1 \mathrm{H}, J=8.80 \mathrm{~Hz}, \mathrm{Ar}-\mathrm{H}), 7.00 \mathrm{~s}(1 \mathrm{H}, \mathrm{OH}), 7.34-7.37 \mathrm{dd}(1 \mathrm{H}, J=8.80$ $\mathrm{Hz}, J=2.57 \mathrm{~Hz}, \mathrm{Ar}-\mathrm{H}), 7.90-7.91 \mathrm{~m}(4 \mathrm{H}, \mathrm{Ar}-\mathrm{H}), 8.03 \mathrm{~d}(1 \mathrm{H}, J=2.57 \mathrm{~Hz}, \mathrm{Ar}-\mathrm{H}) \cdot{ }^{13} \mathrm{C}$ NMR (DMSO- $d_{6}, 100$ MHz) $\delta 122.0,123.6,126.2,129.1,132.6,133.0,134.5,134.8,138.4,140.5,143.4,149.3$, 158.3, 178.3; ESI MS $m / z$ (rel int): $385(\mathrm{M}+\mathrm{H})^{+}(100)$. Found: $\mathrm{C} 49.89 ; \mathrm{H} 2.36$; N 14.55.Anal. Calcd for $\mathrm{C}_{16} \mathrm{H}_{9} \mathrm{BrN}_{4} \mathrm{O}_{3}$ : C 49.91; H 2.38; N 14.57 .

\section{2-(4-(1H-tetrazol-5-yl)phenyl)-3-hydroxy-6-methyl-4H-chromen-4-one (3e)}

A pale yellow solid: Yield 79\%, mp 161-163으. $\mathrm{IR}(\mathrm{KBr})$ vmax $3522(\mathrm{OH}), 3363(\mathrm{NH}), 1606(\mathrm{C}=\mathrm{O})$. ${ }^{1} \mathrm{H}$ NMR (DMSO- $\left.d_{6}, 400 \mathrm{MHz}\right) \delta 2.34 \mathrm{~s}\left(3 \mathrm{H},-\mathrm{CH}_{3}\right), 6.92 \mathrm{~d}(1 \mathrm{H}, J=8.43 \mathrm{~Hz}, \mathrm{Ar}-\mathrm{H}), 7.13 \mathrm{~s}(1 \mathrm{H}, \mathrm{OH}), 7.41 \mathrm{~d}$ $(1 \mathrm{H}, J=8.43 \mathrm{~Hz}, \mathrm{Ar}-\mathrm{H}), 8.10-8.18 \mathrm{~m}(5 \mathrm{H}, \mathrm{Ar}-\mathrm{H}) .{ }^{13} \mathrm{C}$ NMR (DMSO- $\left.d_{6}, 100 \mathrm{MHz}\right) \delta 20.2,117.0,118.5,121.2$, 124.1, 127.9, 129.7, 133.3, 134.4, 135.4, 136.1, 144.3, 153.2, 159.5, 173.3; ESI MS $m / z$ (rel int): $321(\mathrm{M}+\mathrm{H})^{+}$ (100). Found: C 63.75; H 3.78; N 17.49. Anal. Calcd for $\mathrm{C}_{17} \mathrm{H}_{12} \mathrm{~N}_{4} \mathrm{O}_{3}$ : C 63.77; H 3.80; N 17.51.

\section{2-(4-(1H-tetrazol-5-yl)phenyl)-6,8-dichloro-3-hydroxy-4H-chromen-4-one (3f)}

A pale yellow solid: Yield 83\%, mp 155-157 ${ }^{\circ} \mathrm{C}$. IR (KBr) vmax 3523(OH), $3373(\mathrm{NH}), 1604(\mathrm{C}=\mathrm{O})$. ${ }^{1} \mathrm{H}$ NMR (DMSO- $\left.d_{6}, 400 \mathrm{MHz}\right) \delta 7.06 \mathrm{~s}(1 \mathrm{H}, \mathrm{Ar}-\mathrm{H}), 7.23 \mathrm{~s}(1 \mathrm{H}, \mathrm{OH}), 8.14-8.15 \mathrm{~m}(4 \mathrm{H}, \mathrm{Ar}-\mathrm{H}), 8.27 \mathrm{~s}(1 \mathrm{H}, \mathrm{Ar}-$ H). ${ }^{13} \mathrm{C}$ NMR (DMSO- $\left.d_{6}, 100 \mathrm{MHz}\right) \delta 121.4,123.4,126.2,129.1,132.5,132.9,134.4,134.7,138.3,140.4$, 143.3, 149.2, 158.2, 178.2; ESI MS $m / z$ (rel int): $375(\mathrm{M}+\mathrm{H})^{+}{ }^{+}$(100). Found: C 51.22; H 2.15; N 14.93. Anal. Calcd for $\mathrm{C}_{16} \mathrm{H}_{8} \mathrm{Cl}_{2} \mathrm{~N}_{4} \mathrm{O}_{3}$ : C 51.24; $\mathrm{H} 2.17 ; \mathrm{N} 14.95$. 


\section{2-(4-(1H-tetrazol-5-yl)phenyl)-6-chloro-3-hydroxy-7-methyl-4H-chromen-4-one (3g)}

A pale yellow solid: Yield 83\%, mp 174-176 ${ }^{\circ} \mathrm{C}$. IR $(\mathrm{KBr})$ vmax $3523(\mathrm{OH}), 3442(\mathrm{NH}), 1628(\mathrm{C}=\mathrm{O})$. ${ }^{1} \mathrm{H}$ NMR (DMSO- $\left.d_{6}, 400 \mathrm{MHz}\right) \delta 8.19 \mathrm{~s}(1 \mathrm{H}, \mathrm{Ar}-\mathrm{H}), 8.06-8.07 \mathrm{~m}(4 \mathrm{H}, \mathrm{Ar}-\mathrm{H}), 7.15 \mathrm{~s}(1 \mathrm{H}, \mathrm{OH}), 6.99 \mathrm{~s}(1 \mathrm{H}$, $\mathrm{Ar}-\mathrm{H}), 2.43 \mathrm{~s}\left(3 \mathrm{H},-\mathrm{CH}_{3}\right) .{ }^{13} \mathrm{C}$ NMR (DMSO- $\left.d_{6}, 100 \mathrm{MHz}\right) \delta 175.0,161.2,155.0,146.0,141.7,137.8,137.2$, 136.1, 131.5, 129.6, 126.0, 123.0, 120.3, 118.7, 21.9; ESI MS $m / z$ (rel int): $355(\mathrm{M}+\mathrm{H})^{+}(100)$. Found: C 57.56; $\mathrm{H}$ 3.13; N 15.83. Anal. Calcd for $\mathrm{C}_{17} \mathrm{H}_{11} \mathrm{ClN}_{4} \mathrm{O}_{3}$ : C 57.58; H 3.15; N 15.81 .

\section{Biological assay \\ Antibacterial activity}

The synthesized new compounds $\mathbf{3}(\mathbf{a}-\mathbf{g})$ were screened for their Antibacterial activity against different types of bacterial strains such as Gram-negative bacterial strains of Klebsiella pneumonia, Escherichia coli, and Gram-positive bacterial strains of Bacillus subtilis, Staphylococcus aeureus at two different concentration of 10 and $20 \mu \mathrm{g} / \mathrm{mL}$. The cultures were diluted with $5 \%$ saline autoclaved, and the final volume was made with concentration approximately $10^{5}-10^{6} \mathrm{CFU} / \mathrm{mL}$. The synthesized compounds were diluted in DMSO for antibacterial biological assays. For agar disc diffusion method, the liquid form of test compound was soaked on to the disc and then allowed to air dry, such that the disc gets completely saturated with test compound. The saturated chemical discs were introduced onto the upper layer of the medium evenly flooded with the bacteria. The discs were dipped in different chemical samples, were placed over the evenly spread bacterial nutrient media, and incubated at $37^{\circ} \mathrm{C}$ for $24-48 \mathrm{~h}$ for better inhibition of bacteria. The zones of inhibition were measured after 24-48 h. All the experiments were carried out in triplicated and the results were expressed as zone of Inhibition in $\mathrm{mm}$. The zones of inhibition of synthesized compounds $\mathbf{3}(\mathbf{a}-\mathbf{g})$ were compared to the zone of inhibition of standard antibiotic concentrations of gatifloxacin $(10$ and $20 \mu \mathrm{g} / \mathrm{mL})$.

\section{Antifungal activity}

The antifungal activity of synthesized compounds $\mathbf{3}(\mathbf{a}-\mathbf{g})$ were tested against three pathogenic fungi, namely Aspergillus niger, Aspergilus flavus and Fusarium oxysporum by the poison plate technique at a concentration of $50 \mu \mathrm{g} / \mathrm{mL}$. Three kinds of fungi were incubated in PDA at $25 \pm 1{ }^{0} \mathrm{C}$ for 5 days to get new mycelium for antifungal assay, then a mycelium as discs of approximately $0.45 \mathrm{~cm}$ diameter cut from the culture medium were picked up with a sterilised inoculation needle and inoculated in the center of PDA plate. Test compounds were dissolved in DMSO $(10 \mathrm{~mL})$ after that added into the Potato Dextrose Agar medium (PDA, $90 \mathrm{~mL}$ ). The final concentration of compounds into the medium was adjusted to $50 \mu \mathrm{g} / \mathrm{mL}$. The inoculated plates were incubated at $25 \pm 1{ }^{\circ} \mathrm{C}$ for 5 days. Acetone was diluted with sterilised distilled water and used as control, while clotrimazole $(50 \mu \mathrm{g} / \mathrm{mL})$ was used as standard control for each treatment three replicates of experiments were carried out. The radial growth of the fungal colonies was measured on the 5 th day.

\section{Results and discussion}

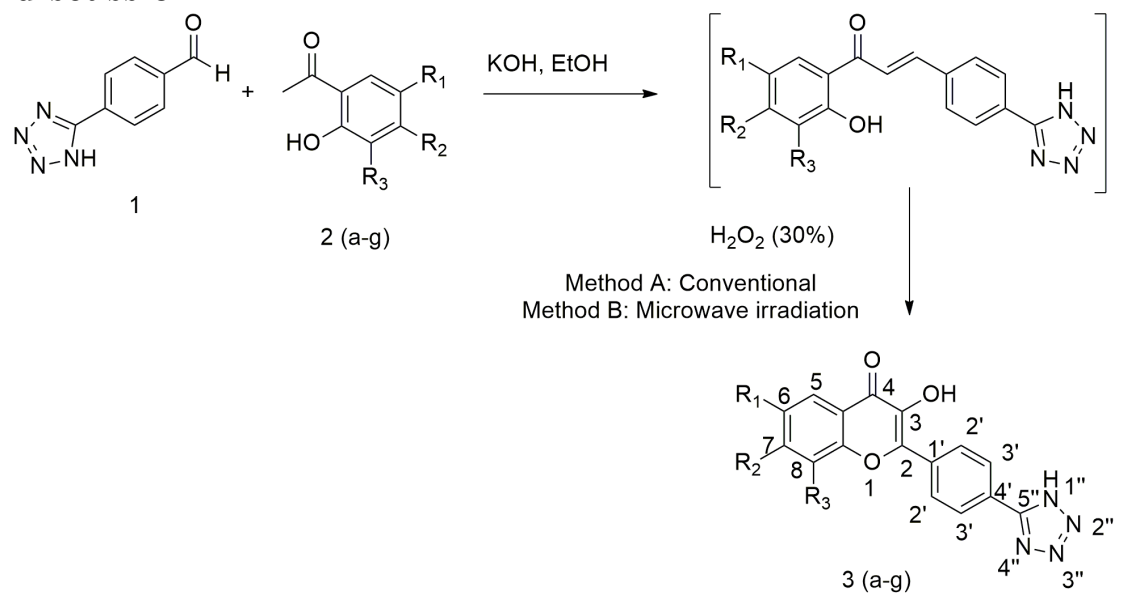




\begin{tabular}{|c|c|c|c|c|c|c|c|}
\hline & $\mathrm{a}$ & $\mathrm{b}$ & $\mathrm{c}$ & $\mathrm{d}$ & $\mathrm{e}$ & $\mathrm{f}$ & $\mathrm{g}$ \\
\hline $\mathrm{R}_{1}$ & $\mathrm{H}$ & $\mathrm{F}$ & $\mathrm{Cl}$ & $\mathrm{Br}$ & $\mathrm{Me}$ & $\mathrm{Cl}$ & $\mathrm{Cl}$ \\
\hline $\mathrm{R}_{2}$ & $\mathrm{H}$ & $\mathrm{H}$ & $\mathrm{H}$ & $\mathrm{H}$ & $\mathrm{H}$ & $\mathrm{H}$ & $\mathrm{Me}$ \\
\hline $\mathrm{R}_{3}$ & $\mathrm{H}$ & $\mathrm{H}$ & $\mathrm{H}$ & $\mathrm{H}$ & $\mathrm{H}$ & $\mathrm{Cl}$ & $\mathrm{H}$ \\
\hline
\end{tabular}

Scheme 1. Synthesis of 2-(4-(1H-tetrazol-5-yl)phenyl)-3-hydroxy-4H-chromen-4-one 3(a-g) under conventional (Method A), Microwave irradiation (Method B) methods.

In the present investigation, some new substituted 2-(4-(1H-tetrazol-5-yl)phenyl)-3-hydroxy- $4 H$ chromen-4-one 3(a-g) have been effectively synthesised using both conventional and microwave irradiation methods. Substituted 2-hydroxyacetophenone 2(a-g) was initially reacted with 4-(1H-tetrazol-5-yl) benzaldehyde [23] to give chalcone, later the reaction mixture was treated with catalytic amount of hydrogen peroxide $\left(30 \% \mathrm{H}_{2} \mathrm{O}_{2}\right)$ in alkaline medium at room temperature to give the corresponding flavonols (3a-g). As a model case, synthesis of derivative $\mathbf{3 b}$ was carried out in both conventional and microwave irradiation method. In conventional method the $\mathbf{3 b}$ was obtained with $61 \%$ yield in $10 \mathrm{~h}$ of stirring at RT, while in microwave irradiation [24] compound $\mathbf{3 b}$ was obtained with $79 \%$ yield in $11 \mathrm{~min}$. The comparisons of yields of the compounds $\mathbf{3}(\mathbf{a}-\mathbf{g})$ in both the methods were depicted in Table 1.

Table 1. Reaction time and yields of the synthesized compounds $3(\mathbf{a}-\mathbf{g})$

\begin{tabular}{|c|c|c|c|c|}
\hline \multirow{2}{*}{ Comp. no } & \multicolumn{2}{|c|}{ Conventional } & \multicolumn{2}{c|}{ MWI } \\
\cline { 2 - 5 } & Time, hr & Yield, $\%$ & Time, min & Yield, \% \\
\hline 3a & 14 & 64 & 9 & 81 \\
\hline 3b & 10 & 61 & 11 & 79 \\
\hline 3c & 11 & 68 & 10 & 84 \\
\hline 3d & 12 & 67 & 12 & 82 \\
\hline 3e & 14 & 61 & 9 & 79 \\
\hline 3f & 13 & 67 & 9 & 83 \\
\hline 3g & 14 & 68 & 10 & 83 \\
\hline
\end{tabular}

The remaining compounds $\mathbf{3 a}, \mathbf{3}(\mathbf{c}-\mathbf{g})$ were synthesized in the similar way using both conventional and microwave conditions. We found that microwave irradiation provides much more faster conversion of the starting compounds and higher yields (reaction time 9-12 min, yields 79-83\%) than conventional heating (reaction time $10-14 \mathrm{~h}$, yields $61-68 \%$ ).

The title compound $\mathbf{3 b}$ was characterized by detailed spectral analyses, including FT-IR, ${ }^{1} \mathrm{H}$ and ${ }^{13} \mathrm{C}$ NMR and mass spectral data as 2-(4-(1H-tetrazol-5-yl)phenyl)-6-fluoro-3-hydroxy-4H-chromen-4-one $\mathbf{3 b}$, that ruled out the formation of corresponding aurone and some other benzofuran derivatives, which were hypothetical to form as by-products in AFO reaction. This assumption of the reaction mechanism and cyclization of the chalcone were supported by literature [25].

In the IR spectrum of $\mathbf{3 b}$, the characteristic carbonyl absorption of flavonol observed at $1606 \mathrm{~cm}^{-1}$ $(>\mathrm{C}=\mathrm{O}),-\mathrm{OH}$ peak is observed at $3522 \mathrm{~cm}^{-1}$ and the $-\mathrm{NH}$ stretching peak appeared at $3363 \mathrm{~cm}^{-1}$. In the ${ }^{1} \mathrm{H} \mathrm{NMR}$ the - $\mathrm{OH}$ proton was appeared as a singlet at $\delta 7.03 . \mathrm{H}_{7}$ proton appeared as doublet of doublet $(J=8.8 \mathrm{~Hz}$ and $J$ $=2.56 \mathrm{~Hz})$ at $\delta 7.40$ and other adjacent proton of $\mathrm{H}_{8}$ as doublet $(J=8.80 \mathrm{~Hz})$ at $\delta 8.07 \mathrm{ppm} . \mathrm{H}_{5}$ proton appeared at $\delta 8.07$ as doublet $(J=2.56 \mathrm{~Hz})$. The remaining proton signals are in the expected region and are in accord with the desired compound. In ${ }^{13} \mathrm{C}$ NMR spectrum of compound $\mathbf{3 b}$, the characteristic carbonyl carbon appeared at $\delta 176.7 \mathrm{ppm}$. All the other carbon signals are in the expected region, which supports the formation of compound $\mathbf{3 b}$. In the ESI-MS mass spectrum of $\mathbf{3 b}$ the base peak was observed at $\mathrm{m} / \mathrm{z} 325$ corresponding to $[\mathrm{M}+\mathrm{H}]^{+}$ion, which further confirmed the structure of $\mathbf{3 b}$. 


\section{Biological evaluation Antibacterial activity}

Table 2. Antibacterial activity of compounds $\mathbf{3}(\mathbf{a}-\mathbf{g})$

\begin{tabular}{|c|c|c|c|c|c|c|c|c|}
\hline \multirow{4}{*}{ Compound } & \multicolumn{8}{|c|}{ Zone of inhibition (mm) } \\
\hline & \multicolumn{4}{|c|}{ Gram positive bacteria } & \multicolumn{4}{|c|}{ Gram negative bacteria } \\
\hline & \multicolumn{2}{|c|}{ S. aureus } & \multicolumn{2}{|c|}{ B. subtilis } & \multicolumn{2}{|c|}{ K. pneumoniae } & \multicolumn{2}{|c|}{ E. coli } \\
\hline & $\begin{array}{c}10 \\
\mu \mathrm{g} / \mathrm{mL}\end{array}$ & $\begin{array}{c}20 \\
\mu \mathrm{g} / \mathrm{mL}\end{array}$ & $\begin{array}{c}10 \\
\mu \mathrm{g} / \mathrm{mL}\end{array}$ & $\begin{array}{c}20 \\
\mu \mathrm{g} / \mathrm{mL}\end{array}$ & $\begin{array}{c}10 \\
\mu \mathrm{g} / \mathrm{mL}\end{array}$ & $\begin{array}{c}20 \\
\mu \mathrm{g} / \mathrm{mL}\end{array}$ & $\begin{array}{c}10 \\
\mu \mathrm{g} / \mathrm{mL}\end{array}$ & $\begin{array}{c}20 \\
\mu \mathrm{g} / \mathrm{mL}\end{array}$ \\
\hline $\mathbf{3 a}$ & 9 & 15 & 7 & 16 & 10 & 16 & 11 & 18 \\
\hline $\mathbf{3 b}$ & 12 & 17 & 11 & 20 & 9 & 18 & 9 & 16 \\
\hline $3 c$ & 11 & 16 & 10 & 18 & 8 & 9 & 8 & 7 \\
\hline 3d & 11 & 19 & 9 & 19 & 6 & 11 & 7 & 11 \\
\hline $3 e$ & 9 & 15 & 6 & 15 & 10 & 18 & 10 & 16 \\
\hline 3f & 13 & 23 & 9 & 22 & 7 & 15 & 8 & 17 \\
\hline $3 g$ & 10 & 17 & 8 & 15 & 11 & 19 & 12 & 17 \\
\hline Gatifloxacin & 13 & 23 & 12 & 25 & 12 & 20 & 13 & 21 \\
\hline
\end{tabular}

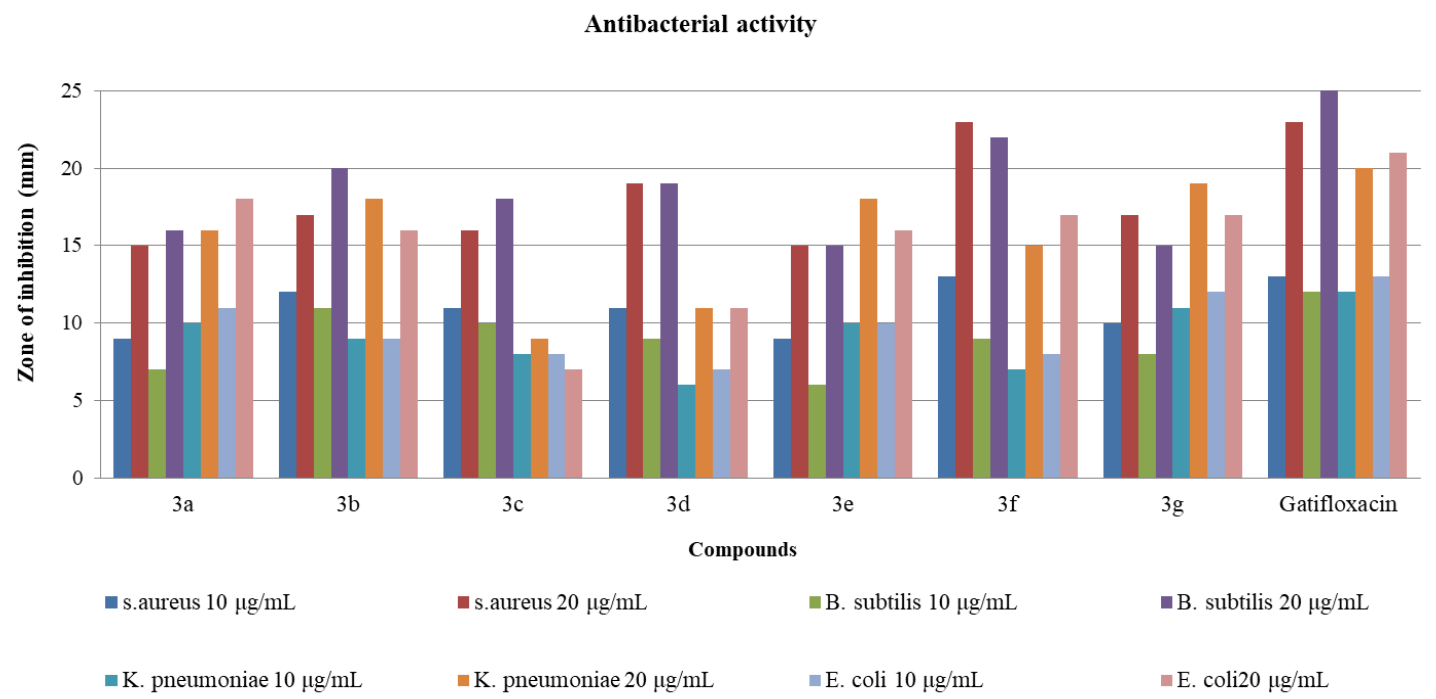

Fig. 1. Graphical representation antibacterial activity of synthesized compounds $\mathbf{3}(\mathbf{a}-\mathbf{g})$.

The newly synthesized title compounds $\mathbf{3 ( a - g )}$ were evaluated for their in-vitro antibacterial activity against Gram-positive strains (such as Bacillus subtilis (MTCC 121), Staphylococcus aureus (MTCC 96)) and Gram-negative strains (such as Escherichia coli, (MTCC 43), Klebsiella pneumonia (MTCC 530)) at various concentration $10 \mu \mathrm{g} / \mathrm{mL}$ and $20 \mu \mathrm{g} / \mathrm{mL}$. The zone of inhibition was measured in $\mathrm{mm}$ and gatifloxacin was used as the standard drug and result shown (Table 2 and Fig. 1). Compounds $\mathbf{3 b}, \mathbf{3 c}, \mathbf{3 d}$ and $\mathbf{3 f}$ were of high potential against gram positive bacterial strains than gram negative bacterial strains. Compounds $\mathbf{3 a}$, $\mathbf{3 e}$ and $\mathbf{3 g}$ were moderately active against positive bacterial strains, and compounds $\mathbf{3 a}, \mathbf{3 e}$, and $\mathbf{3 g}$ shown promise activity against gram-negative strains. The results also demonstrated that the activity of these compounds $\mathbf{3 ( a - g )}$ is influenced by their structures. In conclusion, $\mathbf{3 b}, \mathbf{3 f}$, and $\mathbf{3 g}$ showed potential antibacterial activity against tested organisms. 


\section{Antifungal activity}

The synthesized compounds $\mathbf{3}(\mathbf{a}-\mathbf{g})$ were screened for in-vitro antifungal activity against the fungal organisms such as Aspergillus niger, Aspergillus flavus, and Fusarium oxysporum at the concentration 50 $\mu \mathrm{g} / \mathrm{mL}$ and the results were compared with clotrimazole as standard drug. Upon study of antifungal activity data (Table 3 and Fig. 2), it has been observed that, among all the synthesised compound $\mathbf{3 b}$ and $\mathbf{3 f}$ have shown better activity against three pathogenic fungi, compared to the standard drug. Compounds $\mathbf{3 e}$ and $\mathbf{3 g}$ were showed maximum activity against Fusarium oxysporum, compounds 3a and 3d were shown to promising activity against Aspergillus niger and the compound 3d Shown better activity against Aspergillus flavus. Most of the compounds were shown good activity against the tested fungal strains.

Table 3. Antifungal activity of compounds 3(a-g)

\begin{tabular}{|c|c|c|c|}
\hline Compound & \multicolumn{3}{|c|}{ Zone of Inhibition (mm) } \\
\hline Conc. (50 $\boldsymbol{\mu g} / \mathbf{m L})$ & A. niger & A. flavus & F. oxysporum \\
\hline 3a & 15.8 & 14.2 & 11.4 \\
\hline 3b & 17 & 16.7 & 18 \\
\hline 3c & 13.5 & 14 & 13 \\
\hline 3d & 16.4 & 15.8 & 12.5 \\
\hline 3e & 14 & 13.7 & 17.4 \\
\hline 3f & 16.8 & 16.5 & 17.8 \\
\hline 3g & 12.7 & 14.3 & 17 \\
\hline Clotrimazole & 17.3 & 16.7 & 18.2 \\
\hline
\end{tabular}

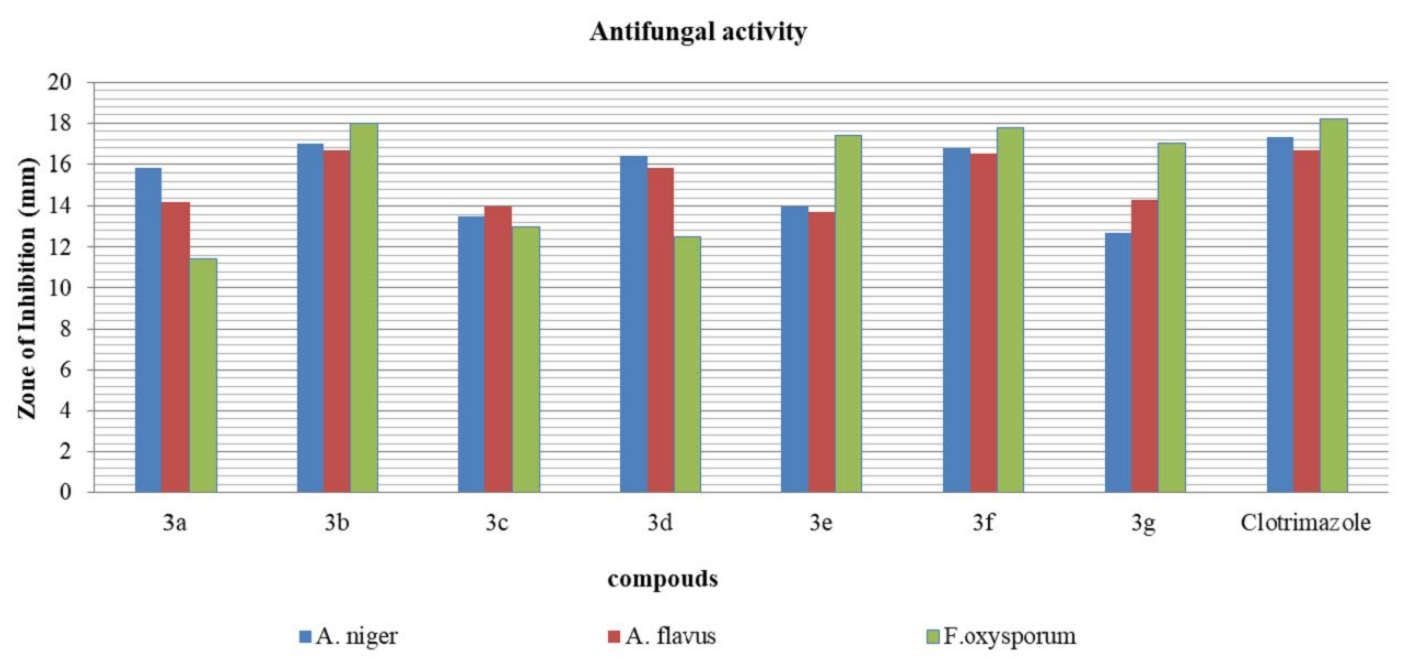

Fig. 2. Graphical representation antifungal activity of synthesized compounds 3(a-g).

In conclusion, we report a convenient, simple and high yielding route for the synthesis of new scaffold flavonol derivatives 3(a-g) under microwave irradiation method in comparison to conventional method. These final compounds were evaluated for their in vitro antimicrobial activity. Compounds $\mathbf{3 b}, \mathbf{3 f}$, and $\mathbf{3 g}$ exhibited promising antibacterial activity and compounds $\mathbf{3 b}$ and $\mathbf{3 f}$ were shows potential antifungal activity. 


\section{Acknowledgments}

We are thankful to the Head, Department of Chemistry, Osmania University, for providing laboratory facilities and CFRD OU, for providing spectral analysis. Nalaparaju Nagaraju thankful to the University Grants Commission, New Delhi, for their financial support. Dongamanti Ashok is thankful to UGC, New Delhi for the award of UGC-BSR fellowship.

\section{References}

1. Genoux, E.; Nicolle, E.; Boumendjel, A. Curr. Org. Chem. 2011, 15, 2608-2615 DOI: https://doi.org/10.2174/138527211796367363

2. Xiao, Z. P.; Peng, Z. Y.; Peng, M. J.; Yan, W. B.; Ouyang, Y. Z.; Zhu, H. L. Mini-Rev. Med. Chem. 2011, 11, 169-177 DOI: 10.2174/138955711794519546

3. Franke, A. A.; Cooney, R. V.; Custer, L. J.; Mordan, L. J.; Tanaka, Y. Adv. Exp. Med. Biol. 1998, 439, 237-248 DOI: https://doi.org/10.1007/978-1-4615-5335-9_17

4. Ashok, D.; Kifah, M. A.; Lakshmi, B. V.; Sarasija, M.; Adam, S. Chem. Heterocycl. Compd. 2016, 52, 172-176 DOI: 10.1007/s10593-016-1852-4

5. Chohan, Z. H.; Rauf, A.; Naseer, M. M.; Somra, M. A.; Supuran, C. T. J. Enzyme Inhib. Med. Chem. 2006, 21, 173-177 DOI: https://doi.org/10.1080/14756360500533059

6. Kim, H. P.; Son, K. H.; Chang, H. W.; Kang, S. S., Nat. Prod. Sci., 1996, 2, 1-8

7. Ercelen, S.; Klymchenko, A. S.; Demchenko, A. P. Anal. Chim. Acta., 2002, 464 (2), $273-287$ DOI: 10.1016/S0003-2670(02)00493-2

8. Algar, J. Flynn, J. P. Proc. Roy. Irish Acad., 1934, 42B, 1-18

9. Oyamada, T. Bull. Chem. Soc. Jopan, 1935, 10, 182-186 DOI: https://doi.org/10.1246/bcsj.10.182

10. Murakami, M.; Irie, T. Proc. Imp. Acad. Tokyo 1935, 11, 229

11. Reichel, L.; Steudel, J. Liebigs Ann. 1942, 553, 83-97

12. Ostrovskii, V. A.; Koldobskii, G. I.; Trifonov, R. E. Comp. Heterocycl. Chem. III., 2008, 6, $257-423$ DOI: https://doi.org/10.1016/B978-008044992-0.00517-4

13. Srinivas, B.; Kumar, P. V.; Reddy, P. N.; Venu, S.; Shyam, P., Krupadanam, G. D. Russ J Bioorg Chem., 2018, 44, 244 DOI: https://doi.org/10.1134/S1068162018020097

14. Mulwad, V. V.; Pawar, R. B.; Chaskar, A. C. J. Korean Chem. Soc., 2008, 52, 249-256 DOI: 10.5012/jkcs.2008.52.3.249

15. Kumar, S. M.; Manjunath, B. C.; Lingaraju, G. S.; Abdoh, M. M. M.; Sadashiva, M. P.; Lokanath, N. K., The FASEB Journal., 2007, 21, 790 DOI:10.4236/csta.2013.23017

16. Bhaskar, V. H.; Mohite, P. B., J. Optoelectron. Biomed. Mater., 2010, 2, 249-259

17. Le Bourdonnec, B.; Meulon, E.; Yous, S.; Goossens, J. F.; Houssin, R.; Hénichart, J. P. J. Med. Chem., 2000, 43, 2685 DOI: $10.1021 /$ jm 9904147

18. Adamec, J.; Waisser, K.; Kuně̌, J.; Kaustová. J. Archiv der Pharmazie, 2005, 338(8), 385-389 DOI: https://doi.org/10.1002/ardp.200400967

19. Upadhayaya, R. S.; Jain, S.; Sinha, N.; Kishore, N.; Chandra, R.; Arora, S. K. Eur. J. Med. Chem., 2004, 39, 579 DOI: 10.1016/j.ejmech.2004.03.004

20. Rajasekaran, A.; Murugesan, S.; Ananda Rajagopal, K. Arch of Pharmacal Res., 2006, 29, $535-540$ DOI: https://doi.org/10.1007/BF02969261

21. Ashok, D.; Rangu, K.; Gundu, S.; Lakkadi, A.; Tigulla, P. Med. Chem. Res., 2017, 26, 1735 DOI: https://doi.org/10.1007/s00044-017-1834-9

22. Ashok, D.; Vijaya Lakshmi, B.; Ravi, S.; Ganesh, A. Med. Chem. Res., 2015, 24, 1487 DOI: 10.1007/s00044-014-1204-9

23. Akhlaghinia, B.; Soodabeh Rezazadeh, J. Braz. Chem. Soc., 2012, 23, 2197 DOI: 10.1590/S0103

24. Ashok, D.; Ravi, S.; Vijaya Lakshmi, B.; Ganesh, A., J. Serb. Chem. Soc., 2015, 80, 1 DOI: 10.2298/JSC141203051A 
25. Serdiuk, I. E.; Roshal, A. D.; Błażejowski, J. Chem. Heterocycl. Compd., 2014, 50, 396 DOI: https://doi.org/10.1007/s10593-014-1487-2 